\title{
Kindergartners' morphological awareness, its instruction and guidance in the Indonesian context
}

\author{
M. Solehuddin ${ }^{*}$, Wawan Gunawan ${ }^{2}$, and Eri Kurniawan ${ }^{2}$ \\ ${ }^{1}$ Department of Educational Psychology and Guidance, Faculty of Education, Universitas Pendidikan Indonesia, \\ Jl. Dr. Setiabudhi No. 229, Bandung, West Java, Indonesia \\ ${ }^{2}$ Department of English Education, Faculty of Language and Literature Education, Universitas Pendidikan Indonesia, \\ Jl. Dr. Setiabudhi No. 229, Bandung, West Java, Indonesia
}

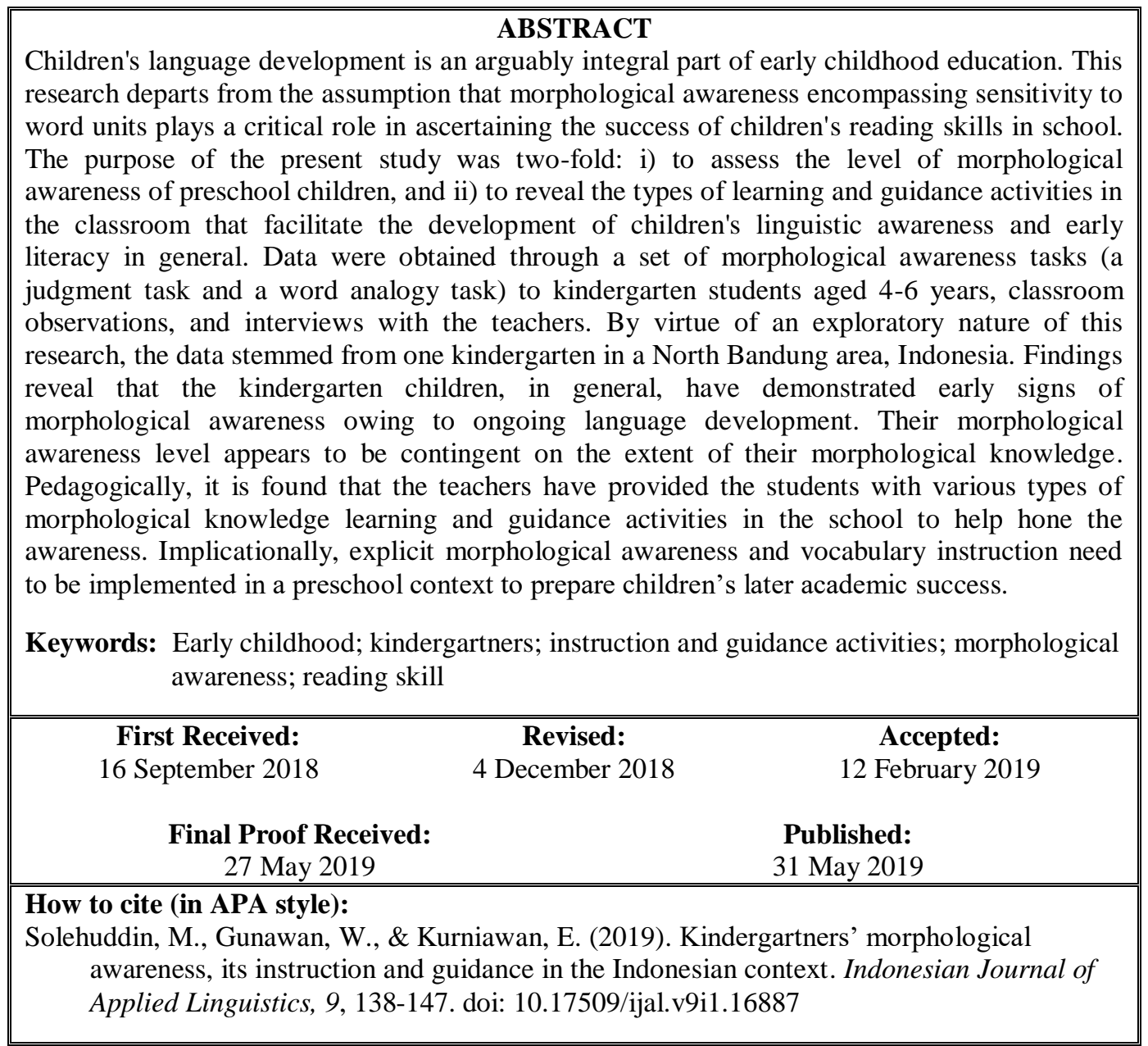

\section{INTRODUCTION}

Language in the context of early childhood development has a central role to play because the process of acquiring language in children coincides with and is influenced by social, cognitive and physiological development (Shatz, 2007). Therefore, language development is one of the crucial components of children's learning both in kindergarten and elementary school. In the Indonesian context, such an assumption is reinforced by the Regulation of the Minister of National
Education of Indonesia Number 58 of 2009 concerning Early Childhood Education Standards which underscores the importance of language learning, especially in early childhood education.

In the realm of early childhood and elementary school education, reading has been construed as a basic language skill that is worthy of the spotlight from both educators and parents (see Irwin, Moore, Tornatore, \& Fowler, 2012), partly because reading skills are the prerequisite for ensuring the success of children in

\footnotetext{
* Corresponding Author

Email: msolehuddin@upi.edu
} 
absorbing knowledge (teaching materials) which are mostly contained in text (books) and even the success of children in their involvement in society (Tong, Deacon, \& Cain, 2014). Recognizing the significance of reading skills that may guarantee children's academic success, as preliminary observation has shown, some parents, especially in Indonesia, begin to teach their reading skills either by themselves at home or by sending their children to a reading training program. Accordingly, educators at early childhood education also respond to this demand by teaching children with a set of systematic and intensive reading activities, most of which merely involve literal reading such as memorizing letters and numbers. Such practice might cause undesirable psychological effects considering that children are entering an age that must be packed with cheerfulness and games through which their full potential will nourish (Solehuddin \& Hatimah, 2007). In addition, to date, there has been no research confirming the positive relationship between explicit reading teaching in kindergarten and children's later reading/writing development in school.

Linguistically, increasing evidence is suggestive that reading skills will emerge when children exhibit linguistic awareness namely awareness of sound units (phonological), word units (morphological) and sentences (syntax). Phonological awareness refers to awareness of the structure of sound units in language (Menn \& Stoel-Gammon, 2005), which is seen as paramount as one of the prerequisites for reading skills (see Gillon, 2018). Research on the phonological awareness of Indonesian children (Mazka, 2014) shows that the children demonstrated a certain degree of phonological awareness at the level of syllables, words and rhythms. They, however, faced difficulties in identifying onset-rime and phonemic properties.

Grammatical awareness inclusive of morphological awareness and syntax, according to Cain (2007), McBride-Chang (2004) and Tong, et al. (2014), refers to the metalinguistic ability to manipulate and reflect the grammatical structure of language. The ability in question includes the ability to compile scrambled words into correct sentences and to correct grammatical errors in sentences. According to Hiebert \& Bravo (2010), a number of experts (such as Carlisle, 2000; Nagy \& Anderson, 1984; Tyler \& Nagy, 1990; White, Powder \& White, 1989) have contended that morphological awareness plays an essential role in determining children's ability to read fluently and meaningfully.

In light of mounting evidence on the significance of morphological awareness as outlined above, researchers investigated the effects of explicit instruction of morphology (e.g., Baumann et al., 2002, Baumann, Edwards, Boland, Olejnik, \& Kame'enui, 2003; Carlisle, 2007). Nunes, Bryant, and Olson (2003), Nunes and Bryant (2006), and Henry (1989) have further provided experimental evidence that morphological instruction is evidently effective in boosting children's word reading and spelling skills.
Interestingly, they also noted that this type of instruction is rare in schools even in the West. It is, of course, of an empirical interest to see whether such an explicit morphology instruction exists in the school under inquiry.

The above-mentioned studies present a portrait of linguistic awareness of early childhood in European and American contexts that factor into children's reading skills in school. However, the examination of language awareness in the Indonesian context has received little attention, particularly for native speakers of Indonesian language. Furthermore, most of the studies regarding language awareness merely focus on gauging phonological and/or morphological aspects of the language. Concerning phonological awareness, for example, Winskel and Widjaja (2007) examined the phonological awareness, letter knowledge, and literacy development of children in Grade 1 and successively in Grade 2. Meanwhile, Mazka (2014) simply investigated kindergarten children's phonological awareness. On morphological awareness, while Asyani (2013) investigated morphological awareness of children in an Islamic kindergarten (Raudhatul Athfal) and its correlation towards their reading abilities, Nurdiansyah (2016) did a quantitative study of children's awareness of inflectional morphology. Lastly, Kurniawan, Komara, and Nurdiansyah (2016) gauged 5-6 aged children's morphological and syntactic awareness.

\section{Morphological awareness}

Morphological awareness refers to the awareness of the structure of language at the word level and involves the ability to change or manipulate the word morpheme structure, which is presented in the form of pairs of words, sentence frames or word analogies (Carlisle, 1995). This also involves the ability to identify root words and their affixed or derived forms (Gafoor \& Remia, 2013). For example, when a child understands that the word talking consists of two smaller meaningful parts (the combination of talk $+-i n g$ ), the child then has demonstrated morphological awareness (Pike, 2011). There are four aspects of morphological awareness which needs to be considered (Apel, 2014): 1) awareness in spoken or written language; 2) awareness in terms of changes in meaning and grammatical class (i.e. inflection or derivation); 3) awareness in terms of changes in structure of the morphemes; 4) awareness in terms of word variety and possible morphemes. However, due to a great deal of the complexity of the morphological system of Indonesian, it appears that there will be challenges in designing a full range of well-structured morphological awareness assessment as the specificity of the morphological aspects of the language needs to be clearly defined.

Recent years have also witnessed a heated discussion on the notion of morphological awareness as many scholars propose their own notion of the topic both on the definition as well as the assessment. For example, Apel (2014) stated that "what is missing from all current definitions is the full level of specificity that 
might guide researchers and practitioners in evaluating students' morphological awareness abilities comprehensively" (p. 198). Among the problematic example of existing studies is the method of assessment. Apel (2014) further claimed that many studies administered morphological awareness in a spoken mode by means of a written instrument. This leads to confusion on which aspect of morphological awareness is assessed-written or spoken language. Another questionable practice in recent studies is in distinguishing morphological awareness and morphological production. Many researchers employed a variety of tasks in assessing morphological awareness by getting a child to produce verbal/spoken responses. This is misleading since language production indeed occurs as a result of unconsciousness, whereas morphological awareness tasks should tap on a child's ability to consciously think about morphemes.

Morphological awareness is believed by a number of experts to play a critical role in determining reading skills in English (among others Carlisle, 2000; Curinga, 2014; Nagy \& Anderson, 1995; Wolter, Wood, \& D'Zatko, 2009) especially in pseudoword reading, reading comprehension, single word reading (Deacon \& Kirby, 2004; Gafoor \& Remia, 2013) and vocabulary acquisition (Deacon \& Kirby, 2004; Kirby \& Bowers, 2009; McBride-Chang, Wagner, Muse, Chow, \& Shu, 2005; Jornlin, 2015). For example, Nagy, Berninger and Abbot (2006) discovered that morphological awareness contributes to reading skills in increasing vocabulary that enhances reading comprehension. Similar findings have been attested in studies in other languagesFrench (e.g., Casalis \& Louis-Alexandre, 2000; Sénéchal, 2000), Dutch (e.g., Assink, Vooijs, \& Knuijt, 2000), and Chinese (e.g., Chung \& Hu, 2007; Ku \& Anderson, 2003). Thus, for kindergarten children, morphological awareness will be helpful in the development of their vocabulary as well as the betterment of their reading comprehension which later on could prepare them to the next level of education.

\section{Morphological knowledge instruction in early childhood}

Children's emergent literacy begins to develop in their early childhood period. Their literacy skills are fundamental to their later reading, writing, and other academic abilities in various learning areas. Learning literacy skills in early childhood aims to help children communicate their ideas and feelings to other people, and also to interpret the message conveyed in their communication process (Christianti, 2013).

Early literacy skills, according to Whitehurst and Lonigan (1998), can be instructionally approached in two ways: code-based and meaning-focused skills. The former primarily focuses on two fundamental concepts that lay the foundation for reading, i.e. alphabet knowledge and phonological awareness. The latter encompasses oral language skills such as vocabulary and grammar.
In terms of vocabulary teaching in preschool, Goodwin and Ahn $(2010,2013)$ reasoned that direct instruction could effectively enhance students' vocabulary. Such teaching helps foster children's morphological awareness and vocabulary knowledge that may lead to later academic success (Ramirez, Walton, \& Roberts, 2014). Contrastingly, Baker, Simons, and Kame'enui (1998) have found that direct vocabulary teaching does not suffice to narrow the vocabulary gaps among children with differing levels of vocabulary. Therefore, a combination of vocabulary teaching and morphological awareness may be an effective measure to circumvent this problem. This is, in fact, what Lyster (2002) has revealed that Norwegian kindergartners showed improvement in awareness after receiving 17-week morphological awareness instruction. Similar findings have been replicated in English (Apel, Brimo, Diehm, \& Apel, 2013) and in French (Casalis \& Colé, 2009).

Guidance also plays a prominent role in early childhood education in assisting children to achieve their full potential. Guidance, by definition, is assistance a teacher provides to make sure students grow in a desirable manner (see Salami, 1989; Oniye \& Durosaro, 2009), to help students' whole person development (Yuen, 2002), and to enhance students' psychological and personal development (Pecku, 1991). In the preschool context, guidance connotes "the process by which care givers guide, pilot, and direct the behaviour acquisition and development of children under their custody" (Oniye \& Durosaro, 2009: 128).

With regard to guidelines of teacher guidance in a kindergarten context, according to Ojeme (2017), a kindergarten teacher can work with a school counsellor to:

a. promote positive teacher-children relationship;

b. work out strategies for promoting effective learning;

c. assist children with special needs for necessary interventions:

d. apply appropriate motivational tools that promote effective learning; and

e. refer young learners with learning difficulties to visit the counsellor for possible intervention and assistance.

It seems palpable that an effective interplay of at least morphological awareness instruction and appropriate guidance strategies may better foster children's improved language development.

\section{Studies on morphological awareness and its teaching in Indonesia}

Studies related to language awareness, specifically on morphological awareness of Indonesian children are relatively minimal. For example, Asyani (2013) conducted a correlational study to investigate the relationship between language awareness and reading ability of children in an Islamic kindergarten. By assessing their phonological, morphological, and 
semantic awareness of the children and their reading ability, it is found that children who performed well on language awareness assessment also performed well on reading task. However, it is found that the morphological awareness of this study has only touched the phonological properties of the morphemes instead of the function of the morphemes. Winskel and Widjaja (2007) performed an assessment of phonological awareness, letter spelling and literacy development of Grade 1 and Grade 2 children. As the focus of the research is the awareness of phonological properties of the language, the morphological awareness task has only touched children ability to eliminate affix in a word without considering the form and meaning.

As the previous studies observed language awareness of children in general and none has, in specific, looked at an instructional practice that targets morphological awareness, a need exists to conduct an exploratory research study that aims explicitly to assess morphological awareness in Indonesian context as well as teaching and guidance process involved in it.

\section{METHOD}

\section{Research design}

A largely qualitative method was adopted in this study since its primary goals are to measure the kindergartens' morphological awareness level; to explore and delineate the learning processes that may foster language development, and lastly to portray the guidance/counselling processes in assisting children in especially their language development. A qualitative descriptive approach becomes relevant for this study for it focuses on the observation of the data in the form of recordings, response, transcription, notes, and interview answers, in order to explore, discover, and clarify claims, as well as to deeply understand the phenomenon in question (Creswell, 2014; Kumar, 2014; Le Compte \& Preissle, 1994). In addition, descriptive statistics was used to measure the awareness level.

\section{Research site and participants}

In light of the fact that this is an exploratory study, the project was undertaken in a laboratory-kindergarten school in Bandung, West Java, Indonesia. As the name implies, this school serves as an apt site for educational research and development, including the study under question. Unlike any other general kindergarten schools, this school is administered by a public teaching university, where scholars are strongly encouraged to conduct scientific inquiries to promote the quality of the school. In addition, this school is also known for its inclusiveness-offering equal access to normally developing children and those with special needs alike-which suits the need of the present research.

The subjects involved in this study consisted of 20 kindergarten children (with ages 4-6 years) from two different classes (4-5-year-old class and 5-6-year-old class), and (b) four class teachers (two from each class). The children consisted of 11 female children and 9 male children, while all the teachers are female.

\section{Instrument}

Two distinct tasks were constructed to measure the children's morphological awareness: a judgment task and a word analogy task. Given a broad range of structures to examine, the primary focus of the measures was on active and passive constructions as well as the respective prefixes, following Nation and Snowling (2000).

The first test was inspired by the judgment task by Apel et al. (2013) and the instrument called 'a suffix choice test' by Nagy, Berninger, Abbott, Vaughn, and Vermeuleun (2003). The instruments consist of eight pictures-taken from one of the most popular children's animated series, Spongebob Squarepants, each of which is accompanied by an incomplete sentence. This task was divided into two steps. Firstly, the students were asked to describe each picture, for example, the instruction was: "Ini gambar apa?/ Ini gambar siapa, sedang apa?" (What kind of picture is this? Who is this? What is he doing?) in order to capture their spontaneous language production. Secondly, they were asked to choose a word in order complete the sentence, for example, 'Tuan $\mathrm{Krab}$ ( $\mathrm{Mr} \mathrm{Crab}$ ) Spongebob' and they were to choose between a) mencubit (is pinching), b) dicubit (is being pinched), and c) bercubit (ungrammatical, to pinch-intransitive) (see Figure 1). This instrument taps the children's morphological awareness of as they need to think and choose the correct affixed word that best fits the sentence in question. In addition, the reason of using pictures in this task is to make the procedure 'lessthreatening' as it resembles a game, as well as to engage the students to cooperatively participate in performing the task (McBride-Chang, et al., 2005).

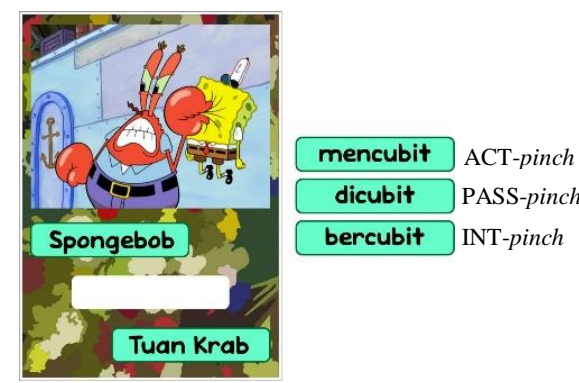

Figure 1. Sample of a judgment task

Note: ACT: Active Marker, PASS: Passive Prefix, INT: Intransitive Prefix 
The second morphological test is called a word analogy task inspired by Kirby, Deacon, Bowers, Izenberg, Wade-Woolley, and Parrila (2012). The children were to first observe a sample and modify a base word (a verb) with a prefix given (see Table 1). The prefix in question is $p e N-$, an agentive derivational suffix that generates a deverbal noun.

Table 1. Sample of a word analogy task

\begin{tabular}{ll}
\hline \multicolumn{2}{c}{ Derivational morphemes } \\
\hline Analogy & Target \\
lari (run) : pelari (a runner) $::$ makan (eat) $:$ & pemakan (an eater) \\
\hline
\end{tabular}

These two tests were delivered orally as the tests do not require children's ability to read. For instance, in the word analogy test, the researcher says, "Kalau orang lari disebut pelari, orang yang makan disebut apa?" (if a person who runs is called a runner, a person who eats is ...). In the second test, the children were not given any options, but instead to orally respond spontaneously.

\section{Data analysis}

The quantitative data used in this was analyzed using descriptive statistics, in which mean, frequency, and percentages were used, given that they reveal central tendencies among the target population (Ransirini, 2006). Meanwhile, the qualitative data, as gathered from observations and interviews, was analyzed or interpreted based on the theory or the results of previous research to ascertain whether the findings have answered the proposed research question (Burton, 2002).

\section{FINDINGS AND DISCUSSION \\ Morphological awareness A judgment test}

Overall, the results of the judgment test show that kindergarten children have demonstrated some extent of morphological awareness in terms of the ability to identify inflectional morphemes in verbs. The extent of awareness can be seen in Table 2 .

Table 2. General findings of judgement task

\begin{tabular}{cccccc}
\hline Number of Participants & Test Items & Number of Answers & Correct Answers & X & Percentage of Correct Answers \\
\hline 20 & 8 & 160 & 108 & 5.4 & $68 \%$ \\
\hline
\end{tabular}

The table above shows that the number of correct answers to the acceptability judgment questions is 108 , $68 \%$ of the total expected answers. In other words, it can be said that from 8 test items, a child averagely answered five correct answers on this morphological awareness test. It is reasonable to suggest that the children under examination have exhibited some degree of morphological awareness, $18 \%$ above a chance level.

\begin{abstract}
A word analogy test
As illustrated below, the children have exhibited some level of morphological awareness in modifying words, as evidenced in the number of correct responses, 110 out of 170 or $65 \%$. This number is marginally lower than the percentage of correct answers in the first task, but still within a relatively similar range.
\end{abstract}

Table 3. Findings according to verbal forms

\begin{tabular}{ccccc}
\hline Number of Participants & Test Items & Number of Answers & Correct Answers & Percentage of Correct Answers \\
\hline 17 & 10 & 170 & 110 & $65 \%$ \\
\hline
\end{tabular}

Table 2 and 3 suggest that the children performed in an identical manner in both tasks, which is reflective of their growing morphological awareness level as far as inflectional and derivational morphology is concerned. The following data of incorrect responses may shed light on the children's ongoing growth of morphological learning.

As Table 4 shows, the children are 'experimenting' with their morphology. The desireable responses are the active transitive forms, but their actual responses are either the intransitive or the passive. There appears some inclination to equate the transitive prefix $m e N$ - to the intransitive ber- (both of which are used in active sentences), which may indicate their understanding of the events depicted in the pictures concerning who is doing what, yet they might be perplexed as to which prefix is the correct one. This state of confusion is further confirmed by additional actual responses, whereby they accepted such illicit forms as *bertangis (INT-cry), *merenang (AV-swim) and *bercubit (INT-pinch). This is suggestive that the children are still in the process of learning morphology.

Table 5 below presents students' incorrect responses in the word analogy task that again substantiates the hypothesis that the students are 'experimenting' with their linguistic knowledge. This is, in fact, not unexpected, as Carlisle (1995) puts it, children's performance on morphological awareness depends on the extent of their morphological knowledge. 
Table 4. Sample of students' incorrect responses in judgment test

\begin{tabular}{llcc}
\hline Expected responses & Children's responses & Number of Occurrences & Total \\
\hline $\begin{array}{l}\text { memegang } \\
\text { (is holding) }\end{array}$ & $\begin{array}{l}\text { ber-pegang } \\
\text { INT-hold } \\
\text { di-pegang } \\
\text { PASS-hold } \\
\text { ber-gambar } \\
\text { INT-draw } \\
\text { di-gambar } \\
\text { (is drawing) }\end{array}$ & 5 & 11 \\
& PASS-draw & 7 & 9 \\
\hline
\end{tabular}

Table 5. Sample of students' incorrect responses in word analogy test

\begin{tabular}{llcc}
\hline Expected responses & Children's responses & Number of Occurrences & Total \\
\hline $\begin{array}{l}\text { menulis-penulis } \\
\text { (write-writer) }\end{array}$ & $\begin{array}{l}\text { pe-tulis } \\
\text { AP-write } \\
\text { peng-tulis } \\
\text { AP-write } \\
\text { peng-makan } \\
\text { AP-eat } \\
\text { pe-cubit } \\
\text { AP-pan-pemakan } \\
\text { (eat-eater) }\end{array}$ & 2 & 3 \\
$\begin{array}{l}\text { mencubit-pencubit } \\
\text { (pinch-pincher) }\end{array}$ & 1 & 2 \\
& AP-pinch & 1 & 2 \\
\hline
\end{tabular}

Note: AP: Agentive Prefix (a derivational prefix that turns a verb into an agentive noun)

What Table 5 demonstrates is the children are attempting to figure out which correct allomorph is well-formed. It should be noted that both pe- and pengare grammatical candidates - as both are licit in forms like pelaut (a sailor) and penggali (a digger). Which prefix is well suited with which base is governed by a set of morphophonological assimilation rules that the students are still learning.

This rather low level of awareness is not entirely anomalous owing to the preschool context of this research. In a school context, for instance, Wolter et al. (2009) observed morphological awareness of 47 firstyear Grade 1 students on their early years of elementary education and discovered that the children's morphological awareness in oral test sits within the score of 7.07 from 15 test items. More specifically, Wolter et al. (2009) found that from 5 test items of inflection, the average score on inflectional words is $3.53(75 \%)$. Research has also reported a similar portrait of morphological awareness underperformance on derivational words. Derwing and Baker (1986), for instance, found that preschoolers were not able to master derivational rules until later ages. In a similar vein, Kuo and Anderson (2006) also argue that English children started acquiring inflectional morphology by 4 years old and its acquisition continues until early elementary grades. Derivational morphology is acquired even later and takes a more extended acquisitional period. Thus, in the present context, it is safe to assume that, on the current range of age, the children's morphological awareness is underway, especially the awareness of inflectional and derivational morphemes.

Another plausible explanation that may account for the children low scores on the two morphological tests is language development as these preschool children are learning a considerable amount of words and their word parts, particularly formal morphology. It is worth noting that the morphological tests utilized in this research solely measure children's awareness of formal Indonesian morphology. One may then hypothesize that if the tests were sensitive to the morphology of both registers-formal and informal, then children's awareness of informal Indonesian morphology would be predictably greater than that of formal counterpart given that the informal morphology is acquired in a naturalistic setting much earlier than the formal one (see Gil, 2008), which children typically learn from school. In Indonesia, the explicit teaching of morphological knowledge begins at Grade 3 (Winskel \& Widjaja, 2007). In English contexts, as Carlisle (2003) reported, the children begin to exhibit morphological awareness in the elementary years. Even first graders are still learning some English morphology, and their morphological knowledge is limited to simple derivations (Carlisle, 1995; Carlisle \& z, 1993). It is reasonable, therefore, to assume that the children's awareness of formal Indonesian morphology is in a developmental stage considering their age range, and they have not received any explicit morphology awareness instruction at this point.

\section{Morphological awareness teaching and guidance process}

In general, on the basis of classroom observations and interviews, being well aware of the importance of early literacy, the teachers in the kindergarten school under examination systematically plan and make various classroom learning activities to help foster language development. Nevertheless, the emphasis of learning merely lies in developing students' vocabulary (morphological knowledge) which they see as a basic skill that can help children communicate functionally. 
Among the activities that they do with the children are teaching vocabulary via flash cards. There is a set of pictures on each card that are familiar to students life such as animals, plants, fruit, objects around the house; there is also a set of vocabularies associated with the visual objects. A teacher will show a picture and say its name, after which the students repeat after the teacher and say it. Typically, five new words are introduced in one session. After sufficient exposure, the students are to match the names with their respective pictures. There is a variation in the way flash cards are exploited for vocabulary learning purposes, but what is of importance here is direct vocabulary teaching. This instructional practice aligns with current research suggesting that explicit instruction has evidently been shown to impact children's vocabulary mastery than implicit instruction (Coyne, McCoach, Loftus, Zipoli \& Kapp, 2009; Marulis \& Neuman, 2010; Penno, Wilkinson \& Moore, 2002).

Another type of learning activity geared towards enriching students' vocabulary is storytelling. This is part of the core learning activities, during which the teacher reads stories to the children. Every week, the teacher tells one short story. The stories come from a range of sources such as children storybooks or even impromptu stories the teacher makes up based on a series of images available at school. The story can be a serial story or a short story that is finished in one sitting. The main objective is two-fold: (i) to expose the students to new vocabularies; and (ii) to familiarize them to reading routines. New words will be repeated in several stories so that the child can easily learn the form and meaning of the words. Like flashcard learning, this type of activity also comes in a variety of variations; one of which is a wayang (traditional Indonesian puppet) performance, whereby the teacher utilizes wayang as characters and a made-up story with a simple plot and a prepared set of new words from the students to learn.

Noteworthy is the fact that all the abovementioned activities are performed in small groups, typically three small groups in each class. The division of children is done through games where children who can answer questions can determine the group they want to choose and take part in. In one of the observations conducted by the researcher, the children were divided into three groups, namely the word group, letters playing group and the mystery box playing group. Both teachers in the class guided activities in groups of words and letters, while children in the mystery box group played independently. The teachers favor storytelling or flash cards over teaching alphabets, numbers, or letter naming for instance. This is a practice prescribed under a developmental view (see Durkin, 1966) where children are not supposed to be taught to read and write before school entry (Adams, 1990).

The instructional practice the teachers have demonstrated are indicative of two crucial elements of effective literacy instruction as Irwin et al., (2012) outline. First is intentional instruction. The teachers under question have specific learning goals when designing learning activities. For example, prior to teaching, they carefully decide which new vocabulary words to teach and in what way. Second is systematic and sequential. As far as vocabulary teaching is concerned, the teachers start with the words the students are most familiar to those new. The choice of new words and learning strategies is suited to the student age range, making it developmentally appropriate.

Another point of pedagogical interest is a great deal of opportunities that the school offers to children to make choices, play actively, and express themselves, in line with Gartrell's (2011) guidance approach. As aforementioned, on the basis of the classroom observations, during core learning activities, the children work in three small groups; the division of which is done through a game where children who correctly answer questions could pick the group they are to choose and be part in. Guided by the teachers, the students play and learn in groups of different themes and activities well suited with the learning material the teachers have set.

As revealed from the interview, there existed a context where a student was found to experience a speech delay or a speech disorder as signalled by unclear articulation or reluctance to communicate with peers. The teachers then took a guidance/counselling initiative. The initial stage was for the teachers to identify the root of the problem by eliciting data from the parent. This is aimed at discovering whether there are genetic factors or some other factors that can trigger speech disorders. After identifying possible causes, the teachers shared the task of specifically helping to restore or remedy the child's speaking ability by first consulting with experts in their field. Guidance efforts were carried out, for example, by paying attention to the child's behavior first, especially in his social interaction with his friends in school. If the child seemed to need assistance with communication, the teacher would immediately help him. This type of guidance practice is in conformity with the guidance strategies as set forth by Ojeme (2017).

\section{CONCLUSION}

This study has demonstrated that preschool children aged 4-6 years in the Indonesian context under examination generally have exhibited early signs of morphological awareness in terms of their sensitivity in inflectional and derivational (formal) Indonesian morphology. It appears that their performance in the morphology tasks hinges on the extent of their morphological knowledge. In other words, their underperformance may be attributed to the morphology learning stage they are undergoing. The teachers also have provided a rich variety of morphology learning activities in the classroom focusing on vocabulary enrichment. Special assistance has been given by the teacher to children who need special assistance. 
Much is to be done in the future to examine what types of school intervention and learning activities and in what way can contribute to children's literacy development, especially in Indonesian contexts. In particular, a future study may entertain the hypothesis of whether some grammatical awareness training may be effectual in raising students' grammatical awareness in Indonesian contexts.

\section{REFERENCES}

Adams, M.J. (1990). Beginning to read: Thinking and learning about print. Cambridge, MA: MIT Press.

Apel, K., Brimo, D., Diehm, E., \& Apel, L. (2013). Morphological awareness intervention with kindergartners and first-and second-grade students from low socioeconomic status homes: A feasibility study. Language, Speech, and Hearing Services in Schools, 44 (2), 161-173. https://doi.org/10.1044/0161-1461(2012/12-0042)

Apel, K. (2014). A comprehensive definition of morphological awareness. Topic in Language Disorders, 34(3), 197-209. https://doi.org/10.1097/tld.0000000000000019

Asyani, A. (2013). Hubungan antara kesadaran linguistik dengan kemampuan membaca dini anak usia dini (Unpublished research paper). Universitas Pendidikan Indonesia, Indonesia.

Assink, E. M., Vooijs, C., \& Knuijt, P. P. (2000). Prefixes as access units in visual word recognition: $\mathrm{A}$ comparison of Italian and Dutch data. Reading and Writing, 12(3), 149-168. https://doi.org/10.1023/a:1008179825696

Baker, S.K. , Simmons, D.C. , Kame'enui, E.J. (1998). Vocabulary acquisition: Research bases. In D. C. Simmons \& E. J. Kame'enui (Eds.), What reading research tells us about children with diverse learning needs: Bases and basics (pp. $183-218$ ). Mahwah, NJ: Erlbaum.

Baumann, J. F., Edwards, E. C., Font, G., Tereshinski, C. A., Kame'enui, E. J., \& Olejnik, S. F. (2002). Teaching morphemic and contextual analysis to fifth-grade students. Reading Research Quarterly, 37(2), 150-176. https://doi.org/10.1598/rrq.37.2.3

Baumann, J. F., Edwards, E. C., Boland, E., Olejnik, S., \& Kame'enui, E. J. (2003). Vocabulary tricks: Effects of instruction in morphology and context on fifth-grade students' ability to derive and infer word meaning. American Educational Research Journal, 40(2), 447-494. https://doi.org/10.3102/00028312040002447

Burton, L. J. (2002). An interactive approach to writing essays and research reports in psychology. Milton, Queensland: John Wiley and Sons Australia, Ltd.

Cain, K. (2007). Syntactic awareness and reading ability: Is there any evidence for a special relationship? Applied Psycholinguistics, 28 (4), 679-694. ttps://doi.org/10.1017/s0142716407070361

Carlisle, J. F. (1995). Morphological awareness and early reading achievement. In L. Feldman (Ed.),
Morphological aspects of language processing (pp. 189-209). Hillsdale, NJ: Erlbaum.

Carlisle, J. F. (2000). Awareness of the structure and meaning of morphologically complex words: Impact on reading. Reading and Writing: An Interdisciplinary Journal, 12(3), 169- 190. https://doi.org/10.1023/a:1008131926604

Carlisle, J. F. (2003). Morphology matters in learning to read: A commentary. Reading Psychology, 24(3-4), 291-322. https://doi.org/10.1080/02702710390227369

Carlisle, J. F. (2007). Fostering morphological processing, vocabulary development, and reading comprehension. In R. K. Wagner, A. E. Muse, \& K. R. Tannenbaum (Eds.), Vocabulary acquisition: Implications for reading comprehension (pp. 78103). NY: Guilford Press.

Carlisle, J. F., \& Nomanbhoy, D. M. (1993) Phonological and morphological awareness in first graders. Applied Psycholinguistics, 14(2), 177-195. https://doi.org/10.1017/s0142716400009541

Casalis, S., \& Louis-Alexandre, M. F. (2000). Morphological analysis, phonological analysis and learning to read French: A longitudinal study. Reading and Writing, 12(3), 303-335. https://doi.org/10.1023/A:1008177205648

Casalis, S., \& Colé, P. (2009). On the relationship between morphological and phonological awareness: Effects of training in kindergarten and in first-grade reading. First language, 29(1), 113-142. https://doi.org/10.1177/0142723708097484

Christianti, M. (2013). Membaca dan menulis permulaan untuk anak usia dini. Jurnal Pendidikan Anak, 2(2), 312-317. doi: 10.21831/jpa.v2i2.3042

Chung, W. L., \& Hu, C. F. (2007). Morphological awareness and learning to read Chinese. Reading and Writing, 20(5), 441-461. https://doi.org/10.1007/s11145-006-9037-7

Coyne, M. D., McCoach, D. B., Loftus, S., Zipoli Jr, R., \& Kapp, S. (2009). Direct vocabulary instruction in kindergarten: Teaching for breadth versus depth. The Elementary School Journal, 110(1), 118. https://doi.org/10.1086/598840

Creswell, J. W. (2014). Research design: Qualitative, quantitative, and mixed methods approaches (4th ed.). Thousand Oaks, CA: SAGE Publication.

Curinga, R. (2014) The effect of morphological awareness on reading comprehension: a study with adolescent Spanish-English emergent bilinguals. Dissertation and Theses, 2014-present. City University of New York.

Deacon, S. H., \& Kirby, J. R. (2004). Morphological awareness: Just "more phonological"? The roles of morphological and phonological awareness in reading development. Applied Psycholinguistics, 25, 223-238. https://doi.org/10.107.S0124716404001117

Derwing, B.L. \& W.J. Baker (1986). On assessing morphological development. In P.J. Fletcher \& M. Gannan (Eds.), Language acquisition: studies in 
first language development, $2^{\text {nd }}$ edition, pp. 326328. Cambridge, Cambridge University Press.

Durkin, D. (1966). Children who read early. New York: Teachers College Press.

Gafoor, K. A. \& Remia, K. R. (2013). Influence of phonological awareness, morphological awareness, and non-verbal ability on reading comprehension in Malayalam. Guru Journal Behavioural and Social Sciences, 1(3), 128-138.

Gartrell, D. (2011). A guidance approach for the encouraging classroom. Belmont, CA: Wadsworth Cengage Learning.

Gil, D. (2008). The acquisition of voice morphology in Jakarta Indonesian. In Gagarina, N. \& Gulzow, I. (Eds). The acquisition of verbs and their grammar: The effect of particular language (p0p. 201-227). Dochredt: Springer.

Gillon, G. T. (2018). Phonological awareness: From research to practice (2nd ed.). New York: The Guilford Press.

Goodwin, A. P., \& Ahn, S. (2010). A meta-analysis of morphological interventions: Effects on literacy achievement of children with literacy difficulties. Annals of dyslexia, 60(2), 183-208. https://doi.org/10.1007/s11881-010-0041-x

Goodwin, A. P., \& Ahn, S. (2013). A meta-analysis of morphological interventions in English: Effects on literacy outcomes for school-age children. Scientific Studies of Reading, 17(4), 257-285. https://doi.org/10.1080/10888438.2012.689791

Henry, M. K. (1989). Children's word structure knowledge: Implications for decoding and spelling instruction. Reading and Writing: An Interdisciplinary Journal, 1(2), 135-152. https://doi.org/10.1007/bf00377467

Hiebert, E.H., \& Bravo, M., (2010). Morphological knowledge and learning to read in English. In D. Wyse, R. Andrews, \& J. Hoffman (Eds.), International handbook of English, language and literacy teaching (pp. 87-97). Oxford, UK: Routledge.

Irwin, J. R., Moore, D. L., Tornatore, L. A., \& Fowler, A. E. (2012). Expanding on early literacy. Children \& Libraries: The Journal of the Association for Library Service to Children, 10(2), 20-28.

Jornlin, M. (2015). The role of morphological awareness in vocabulary acquisition. Langues Et Linguistique, $35,57-63$

Kirby, J. R., Deacon, S. H., Bowers, P. N., Izenberg, L., Wade-Woolley, L., \& Parrila, R. (2012). Children's morphological awareness and reading ability. Reading and Writing, 25(2), 389-410. https://doi.org/10.1007/s11145-010-9276-5

Kirby, J. R. \& Bowers, P. N., (2009). Effects on morphological instruction on vocabulary acquisition. Read and Write, 23, 515-537. doi:10.1007/s11145-009-9172-z

Ku, Y. M., \& Anderson, R. C. (2003). Development of morphological awareness in Chinese and English. Reading and Writing, 16(5), 399-422.
Kumar, R. (2014). Research methodology a step by step guide for beginners 4th edition. London: SAGE Publication.

Kuo, L. \& Anderson, R.C. (2006). Morphological awareness and learning to read: A cross-language perspective. Educational Pscyhologist, 41(3): 161180. doi: 10.1207/s15326985ep4103_3

Kurniawan, E., Komara, T., \& Nurdiansyah, M.S.M. (2016). Kesadaran morfologis dan sintaksis anak usia dini: studi kasus di PAUD Bandung. Proceeding of Konferensi Linguistik Tahunan Atma Jaya 14.

Le Compte, M.D., \& Preissle, J. (1994). Qualitative research: What it is, what it isn't, and how it's done. In Bruce Thompson (Ed.) Advances in Social Science Methodology, 3, 141-163.

Lyster, S. A. H. (2002). The effects of morphological versus phonological awareness training in kindergarten on reading development. Reading and Writing, 15(3-4), 261-294.

Marulis, L. M., \& Neuman, S. B. (2010). The effects of vocabulary intervention on young children's word learning: A meta-analysis. Review of educational research, 80(3), 300-335.

Mazka, F. (2014). Kajian kesadaran fonologi anak: studi deskriptif kualitatif pada anak-anak 5-6 tahun di TK Lab. School UPI Bandung (Unpublished master's thesis). Universitas Pendidikan Indonesia, Indonesia.

McBride-Chang, C. (2004). Children's literacy development. London: Arnold.

McBride-Chang, C., Wagner, R.K., Muse, A., Chow, B.W.Y., \& Shu, H. (2005). The role of morphological awareness in children's vocabulary acquisition in English. Applied Psycholinguistic 26(3), 415-435. https://doi.org/10.1017/s014271640505023x

Menn, L. \& Stoel-Gammon, C. (2005). Phonological development: learning sounds and sound patterns. In Berko Gleason J (Ed.), The development of language, (pp. 62-77). Boston, MA: Pearson Education.

Nagy, W.E., Berninger, V.W., \& Abbot, R.D. (2006) Contribution of morphology beyond phonology to literacy outcomes of upper elementary and middleschool students. Journal of Educational Psychology, 98(1), 134 - 147. doi:10.1037/0022-0663.98.1.134

Nagy, W., Berninger, V., Abbott, R., Vaughan, K., \& Vermeulen, K. (2003). Relationship of Morphology and Other Language Skills to Literacy Skills in At-Risk Second-Grade Readers and At-Risk Fourth-Grade Writers. Journal of Educational Psychology, 95(4), 730-742. http://dx.doi.org/10.1037/0022-0663.95.4.730

Nagy, W.E. \& Anderson, R.C. (1984) How Many Words Are There in Printed School English. Reading Research Quarterly, 19, 304-330. http://dx.doi.org/10.2307/747823

Nagy, W. E. \& Anderson, R., C. (1995). Metalinguistic awareness and literacy acquisition in different 
languages (Technical reports). University of Illinois at Urbana-Champaign.

Nation, K. \& Snowling, M.J. (2000). Factors influencing syntactic awareness skills in normal readers and poor comprehenders, Applied Psycholinguistics, 21(2), 229-241 https://doi.org/10.1017/s0142716400002046

Nunes, T. \& Bryant, P. (2006). Improving literacy by teaching morphemes. New York: Routledge.

Nunes, T., Bryant, P., \& Olsson, J. (2003). Learning morphological and phonological spelling rules: An intervention study. Scientific Studies in Reading, 7(3), 289-307. https://doi.org/10.1207/s1532799xssr0703_6

Nurdiansyah, M. S. (2016). Morphological awareness of Indonesian kindergarten children aged 5-6: A case of inflection (Unpublished research paper). Universitas Pendidikan Indonesia, Indonesia.

Ojeme, A. (2017). Integrating counselling into early childhood education in Nigeria: The benefits, challenges and implications for practice. British Journal of Education, 5(11), 68-76.

Oniye, A.O., \& Durosaro, I.A. (2009). Guidance and behaviour management in early childhood: Need for reform in child care development education. Edo Journal of Counselling, 2(2); 127-134. https://doi.org/10.4314/ejc.v2i2.60848

Pecku, N.K. (1991). Introduction to guidance for training colleges (2nd ed.). Accra: University of Ghana Press.

Penno, J. F., Wilkinson, I. A., \& Moore, D. W. (2002). Vocabulary acquisition from teacher explanation and repeated listening to stories: Do they overcome the Matthew effect?. Journal of educational psychology, 94(1), 23. https://doi.org/10.1037//0022-0663.94.1.23

Pike, K. (2011). Morphological awareness dynamic assessment task in third-grade children: A feasibility study (undergraduate honors theses). Utah State University.

Ramirez, G., Walton, P., \& Roberts, W. (2014). Morphological awareness and vocabulary development among kindergarteners with different ability levels. Journal of Learning Disabilities, 47(1), 54-64. https://doi.org/10.1177/0022219413509970

Ransirini, D. S. (2006). Motivation patterns among Sri Lankan undergraduates: A social constructionist approach (Unpublished doctoral dissertation). University of Malaya, Malaysia.

Ministry of National Education of Indonesia . (2009).
Regulation of the Minister of National Education of Indonesia Number 58 of 2009 concerning Early Childhood Education Standards. Retrieved from https://www.paud.id/2014/05/permendiknas-58tahun-2009-standar-paud.html

Salami, A. A. (1989). The meaning of teaching. In E. A. Adeoye \& A. A. Salami (Eds.). A guide book on approaches to teaching. Ilorin: My Grace Graphic Reproduction Company.

Sénéchal, M. (2000). Morphological effects in children's spelling of French words. Canadian Journal of Experimental Psychology/Revue Canadienne de Psychologie Expérimentale, 54(2), 76. https://doi.org/10.1037/h0087331

Shatz, M. (2007). On the development of the field of language development. In E. Hoff \& M. Shatz (Eds.), Blackwell handbook of language development (pp.1-15). London: Wiley-Blackwell.

Solehuddin, M. \& Hatimah, I. (2007). Pendidikan anak usia dini. Bandung: Pedagogiana Press.

Tong, X., Deacon, S. H., \& Cain, K. (2014). Morphological and syntactic awareness in poor comprehenders: another piece of the puzzle. Journal of Learning Disabilities, 47 (1), 22-33. https://doi.org/10.1177/0022219413509971

Tyler, A., \& Nagy, W. (1989). The acquisition of English derivational morphology. Journal of Memoryand Language, 28, 649-667.

White, T.G., Power, M.A. \& White, S. (1989). Morphological analysis: Implicationsfor teaching and understanding vocabulary growth. Reading ResearchQuarterly, 24, 283-304.

Whitehurst G. J., \& Lonigan C. J., (1998). Child development and emergent literacy. Child Development 69(3), 848-872. https://doi.org/10.2307/1132208

Winskel, H., \& Widjaja, V. (2007). Phonological awareness, letter knowledge, and literacy development in Indonesian beginner readers and spellers. Applied Psycholinguistics, 28(1), 23-45. https://doi:10.1017.S0142716407070026

Wolter, J.A., Wood, A., \& D'Zatko, K. (2009). The influence of morphological awareness on first-grade children's literacy development. Language, Speech, and Hearing Services in the Schools, 40(3), 1-13. https://doi.org/10.1044/0161-1461(2009/08-0001)

Yuen, M. (2002). Exploring Hong Kong Chinese guidance teachers' positive beliefs: A focus group study. International Journal for the advancement of Counselling, 24(3), 169-182. https://doi.org/10.1023/A:1022987421355 